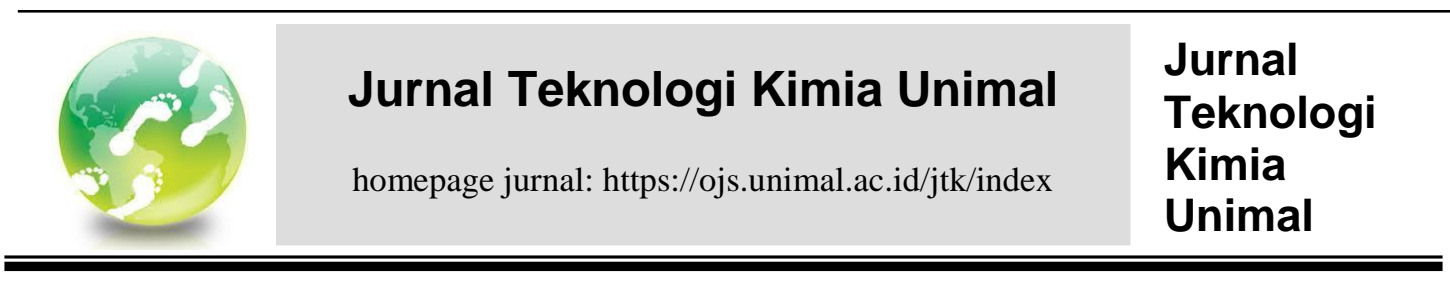

\title{
PENGARUH WAKTU DAN KUAT ARUS PADA PENGOLAHAN AIR PAYAU MENJADI AIR BERSIH DENGAN PROSES ELEKTROKOAGULASI
}

\author{
Masrullita*, Lukman Hakim*, Rizka Nurlaila*, Nur Azila \\ Jurusan Teknik Kimia, Fakultas Teknik, Universitas Malikussaleh \\ Kampus Utama Cot Teungku Nie Reuleut, Muara Batu, Aceh Utara - 24355 \\ Korespondensi:e-mail: masrullita@unimal.ac.id
}

\begin{abstract}
Abstrak
Air payau biasa terjadi akibat intrusi air asin ke air tanah. Hal ini karena degradasi lingkungan. Air payau yang mengandung pencemaran logam tingkat tinggi seperti $\mathrm{Fe}, \mathrm{Cl}, \mathrm{Mn}, \mathrm{Zn}$, dll. Air payau juga biasanya memiliki kadar TDS (Total Dissolved Solid), total kesadahan yang tinggi dan nilai $\mathrm{pH}$ air payau bersifat asam. Oleh karena itu, air payau harus diolah terlebih dahulu agar layak untuk digunakan sebagai air tawar. Instalasi pengolahan air payau dijalankan berdasarkan elektrokoagulasi. Tujuan dari penelitian ini adalah untuk menkaji pengaruh waktu dan kuat arus terhadap menetralkan $\mathrm{pH}$, dan menurunkan kadar TDS, total kesadahan dan Mn pada air payau. Parameter yang diuji meliputi pH, TDS, total kesadahan dan Mn menggunakan AAS. Proses elektrokoagulasi menggunakan daya listrik yang mengalir searah dengan elektroda. Reaktor elektrokoagulasi dipasangkan dengan kabel yang dihubungkan ke catu daya kemudian dihubungkan ke arus listrik dengan variasi waktu (20, 50, 80 dan 110 menit) dan variasi arus $(1,2 ; 1,6 ; 2 ; 2,2$; dan $2,6 \mathrm{~A})$. Hasil penelitian ini menunjukan bahwa kondisi terbaik penurunan TDS pada waktu 110 menit dan kuat arus 2,2 A yaitu $940 \mathrm{mg} / \mathrm{l}$, total kesadahan pada waktu 110 menit dan kuat arus 1,6 A yaitu $480 \mathrm{mg} / \mathrm{l}$, dan nilai $\mathrm{pH}$ yang terbaik pada waktu 80 menit dan 110 menit dengan kuat arus 0,8 A yaitu 7 . Terjadi penurunan pada konsentrasi Mn pada waktu 110 menit dan kuat arus 1,6 A yaitu $0.0124 \mathrm{mg} / \mathrm{l}$ dan perubahan warna setelah elektrokoagulasi.
\end{abstract}

Kata Kunci: Air payau, elektrokoagulasi, kuat arus, TDS

\section{Pendahuluan}

Kebutuhan akan pentingnya air tidak diimbangi dengan kesadaran untuk melestarikan air, sehingga memberikan dampak yang besar terhadap kesehatan maupun sosial. Pengadaan air bersih di Indonesia khususnya untuk skala yang besar masih terpusat diperkotaan dan dikelola oleh Perusahaan Air Minum (PAM) kota yang bersangkutan. Sekitar 16, 42 juta jiwa penduduk Indonesia merupakan 
masyarakat yang hidup di kawasan pesisir. Masih rendahnya produktivitas mereka menyebabkan mereka sulit untuk keluar dari ketidaksejahteraan. Kurangnya pengetahuan masyarakat mengenai pengolahan air bersih ini akan berdampak pada kesehatan masyarakat. Untuk menanggulangi masalah tersebut, maka dikembangkan alat untuk memproduksi air bersih dan air minum yang dapat menaikkan produktivitas sehingga mampu meningkatkan tingkat kesejahteraan mereka.

Untuk memenuhi akan kebutuhan air tawar manusia telah mengembangkan sistem pengolahan air payau dengan metode elektrokoagulasi. Elektrokoagulasi merupakan salah satu metode yang dapat digunakan untuk menurunkan kadar TDS, kandungan logam dan pH sesuai dengan Permen LH No.5 tahun 2014. Elektrokoagulasi ini merupakan proses koagulasi atau penggumpalan dengan tenaga listrik melalui proses elektrolisis untuk mengurangi atau menurunkan ionion logam dan dan partikel-partikel di dalam air. Prinsip dasar dari elektrokoagulasi adalah reaksi reduksi dan oksidasi (redoks). Dalam suatu sel elektrokoagulasi, peristiwa oksidasi terjadi di elektroda (+) yaitu anoda, sedangkan reduksi terjadi di elektroda (-) yaitu katoda. Pada akhirnya terbentuk flokulan yang akan mengikat kontaminan maupun partikel - partikel dari air baku tersebut. Proses Elektrokoagulasi dikenal juga sebagai elektrolisis gelombang pendek (Wiyanto et al, 2014).

Reaktor elektrokoagulasi merupakan sel elektrokimia, dimana dalam reaktor tersebut disusun elektroda-elektroda yang akan berkontak dengan air yang akan diolah. Aluminium merupakan logam yang sering digunakan sebagai elektroda dalam proses elektrokoagulasi. Semakin ke kiri dari sistem deret potensial ini maka akan semakin mudah suatu unsur untuk tereduksi dan semakin ke kanan maka akan mudah teroksidasi. Oleh karena itu alumunium sering digunakan sebagai elektroda di dalam proses elektrokoagulasi karena akan lebih gampang tereduksi didalam air dan akan membentuk ion $\mathrm{Al}^{3+}$ yang akan berikatan dengan ion $\mathrm{OH}^{-}$yang terbentuk dari katoda dan akan mengikat kontaminan atau partikel tersuspensi yang terdapat dari air (Malakootian, 2009). 
Tujuan dilakukannya penelitian ini adalah untuk mengetahui penerapan metoda elektrokoagulasi dapat digunakan untuk menurunkan TDS, total kesadahan, logam $\mathrm{Mn}$ dan penetralan $\mathrm{pH}$ pada air payau.

\section{Bahan dan Metode}

Bahan dan peralatan yang diperlukan dalam penelitian ini antara lain air payau Mesjid Jamik Lhokseumeuwae, EBT, EDTA, buffer $\mathrm{pH}$ 10. reaktor listrik dengan elektroda aluminiun panjang $15 \mathrm{~cm}$, lebar $15 \mathrm{~cm}$, jarak elektroda $3 \mathrm{~cm}$ dan jumlah elektroda 6 buah, serta dilengkapi dengan perangkat sumber arus DC.

Sampel air payau diambil dari air sumur masjid Jamik di daerah Lhokseumawe, Aceh. Penelitian dilakukan pada empat variasi waktu yaitu 50, 80 dan 110 menit, serta divariasikan juga pada lima kondisi kuat arus yaitu 1,2;1,6 ;2; dan 2,2.

Prosedur pengolahan air payau menjadi air bersih ini meliputi beberapa tahapan yaitu analisa parameter awal sampel air payau (kadar TDS, total kesadahan, nilai $\mathrm{pH}$, kandungan logam $\mathrm{Mn}$ ), proses elektrokoagulasi, dan analisa parameter air payau hasil olahan (kadar TDS, total kesadahan, nilai $\mathrm{pH}$, kandungan logam Mn). Rangkaian pengolahan air payau dapat dilihat pada gambar 2.1 .

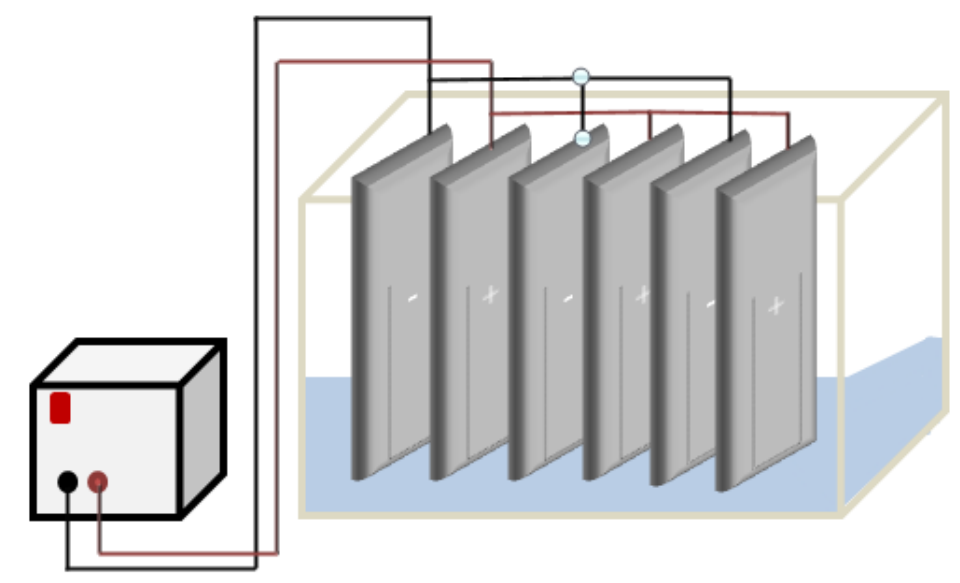

Gambar 2.1 Rangkaian alat proses elektrokoagulasi

\section{Hasil dan Diskusi}

\subsection{Analisa Awal Air Payau}


Analisa sampael awal bertujuan untuk memperoleh data karateristik air payau sebelum dilakukan proses elektrokoagulasi. Adapun hasil analisa sampel awal air payau dapat dilihat pada tabel 3.1.

Tabel 3.1 Hasil Analisa Sampel Awal Air Payau

\begin{tabular}{ccc}
\hline Parameter & $\begin{array}{c}\text { Sampel Air } \\
\text { Payau }\end{array}$ & $\begin{array}{c}\text { Permenkes RI } \\
\text { No.32 tahun 2017 }\end{array}$ \\
\hline TDS & $1430 \mathrm{mg} / \mathrm{l}$ & $1000 \mathrm{mg} / \mathrm{l}$ \\
pH & 7,5 & $6,5-9$ \\
Kosentrasi Mn & $0,08 \mathrm{mg} / 1$ & $0,5 \mathrm{mg} / \mathrm{l}$ \\
Total Kesadahan & $2565 \mathrm{mg} / 1$ & $500 \mathrm{mg} / 1$ \\
\hline
\end{tabular}

Berdasarkan data hasil analisa pada Tabel 3.1, dapat diketahui bahwa terdapat dua parameter yang tidak sesuai dengan baku mutu yaitu kesadahan dan TDS. Oleh karena itu dilakukan elektrokoagulasi menggunakan elektroda alumunium untuk mengurangi kesadahan dan TDS pada air payau. Proses elektrokoagulasi dilakukan dalam dua variasi, yaitu variasi waktu dan kuat arus.

\subsection{Pengaruh Waktu dan Kuat Arus Terhadap TDS}

Adapun pengaruh waktu dan kuat arus terhadap TDS pada air payau bisa kita lihat pada gambar 3.1

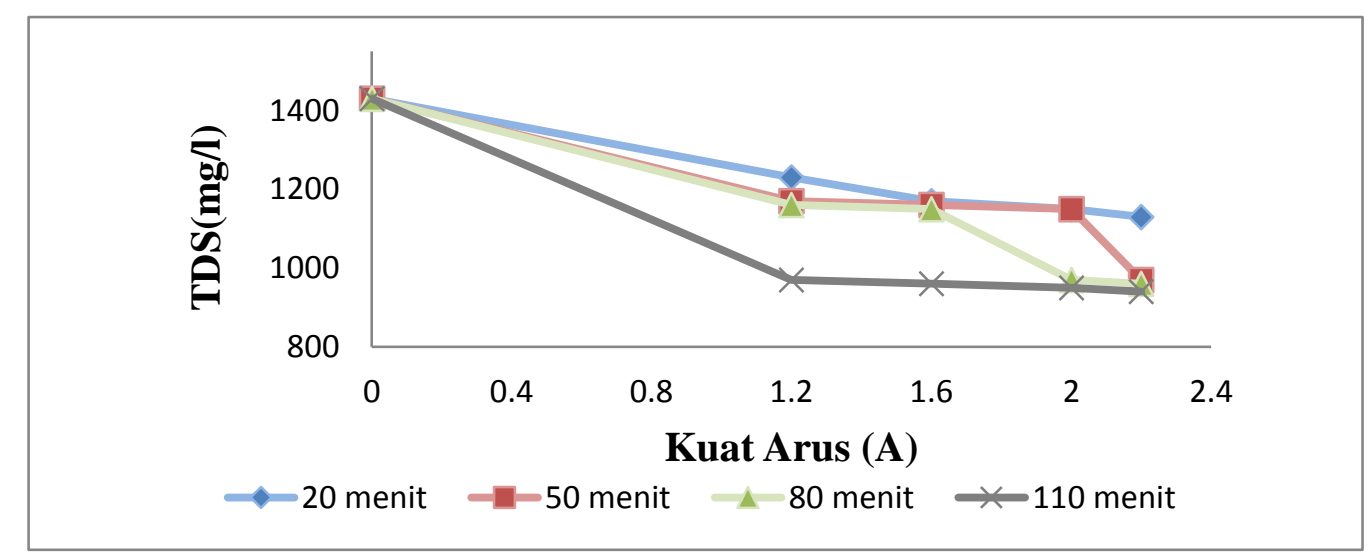

Gambar 3.1 Pengaruh Waktu Kuat Arus Terhadap TDS Dalam Sampel Air Payau 
Berdasarkan data pada Gambar 3.1, pengaruh waktu dan kuat arus terhadap TDS yang di hasilkan, dapat kita lihat hasil yang di dapatkan terhadap TDS terjadi penurunan. Hal ini karena salah satu faktor yang mempengaruhi proses elektrokoagulasi adalah adanya arus listrik dan lama waktu kontak dalam reaktor menyebabkan ion-ion yang dilepaskan oleh elektroda aluminium menghasilkan aluminium hidroksida yang mampu mengikat bahan-bahan organik seperti tannin membentuk flok-flok dan mampu menngumpalkan padatan tersuspensi dalam air payau, sehingga kadar TDS dalam air payau semakin kecil.

Pada waktu 50 menit, 80 menit dan 110 menit penurunan TDS terbesar pada kuat arus 2,2 A yaitu $970 \mathrm{mg} / \mathrm{l}, 960 \mathrm{mg} / \mathrm{l}$, dan $940 \mathrm{mg} / \mathrm{l}$. Maka grafik perubahan kadar TDS sesuai dengan penelitian Alperdo (2019), semakin besar kuat arus dan semakin lama waktu kontak maka semakin besar penurunan TDS.

Pada waktu kontak 110 menit penyisihan TDS mengalami penurunan. Menurunnya penyisihan TDS terjadi karena kejenuhan pada pelat elektroda yang digunakan dikarenakan flok yang menutupi permukaan pelat elektroda. Ketika arus listrik mengalir dari waktu ke waktu, ion aluminium yang keluar dari anda dan ion hidroksida dari katoda akan terus bertambah sehingga jumlah flok yang terlalu banyak akan menyebabkan kejenuhan pada pelat elektroda sehingga kemampuan elektroda untuk menarik polutan dalam air payau akan berkurang

Hasil analisis TDS sampel air payau sebelum elektrokoagulasi yaitu 1.430 mg/l. Hasil tersebut tidak memenuhi persyaratan baku mutu PermenKes RI nomor 32 tahun 2017 yaitu $1000 \mathrm{mg} / \mathrm{l}$. TDS terendah terjadi pada kuat arus 2,2 A pada waktu kontak 110 menit yaitu 940 mg/l.

\subsection{Pengaruh Waktu dan Kuat Arus Terhadap Nilai pH}

Adapun pengaruh waktu dan kuat arus terhadap nilai $\mathrm{pH}$ pada air payau bisa kita lihat pada gambar 3.2 dibawah ini. 


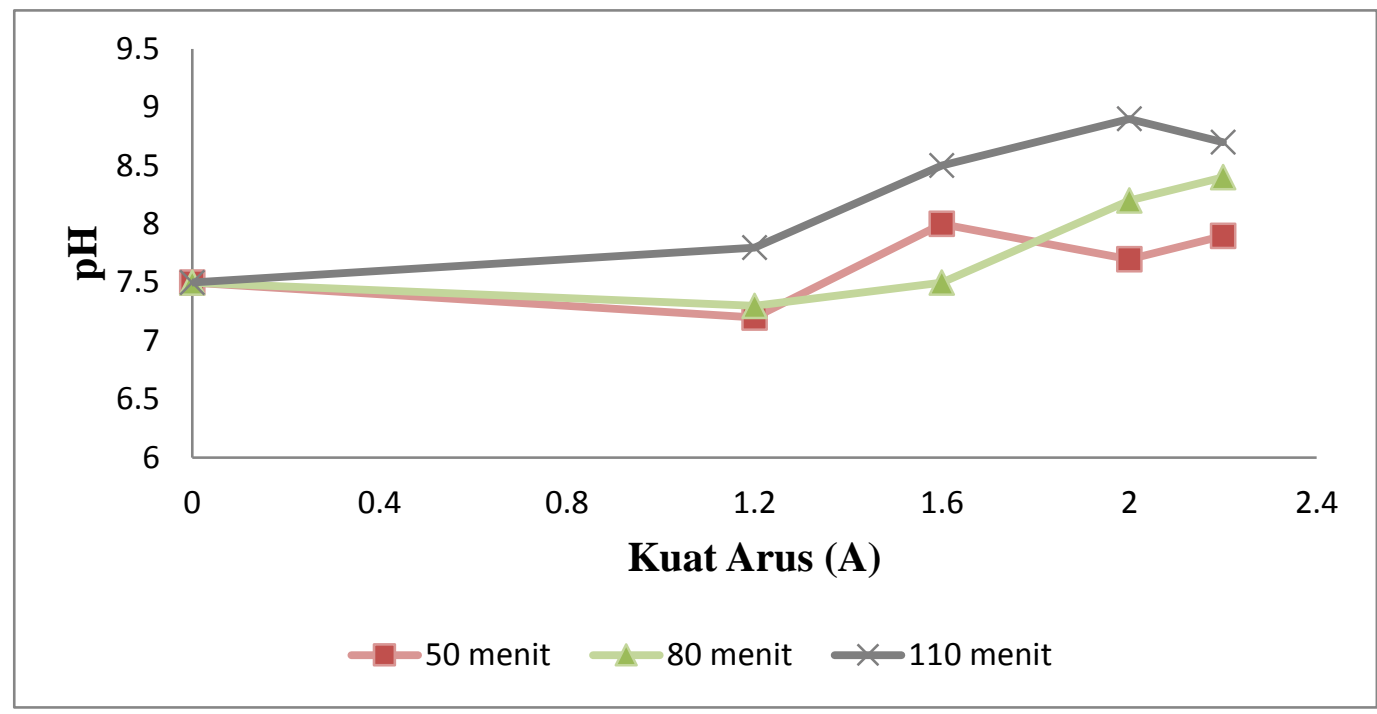

Gambar 3.2 Pengaruh Waktu Kuat Arus Terhadap Nilai Ph Dalam Sampel Air Payau

Berdasarkan data pada Gambar 4.2, dapat di lihat bahwa terjadi kenaikan nilai pH. Hal ini disebabkan oleh terbentuknya ion $\mathrm{OH}$ - pada katoda selama proses berlangsung. Dengan bertambahnya $\mathrm{OH}$ - didalam air payau akan menyebabkan kenaikan pH. Menurut Prabowo (2012), pada proses elektrokoagulasi yang terjadi, semakin banyak ion $\mathrm{OH}^{-}$yang dihasilkan melalui reduksi air pada katoda maka nilai $\mathrm{pH}$ atau kebasaan dari air payau yang diolah akan semakin meningkat. Wiyanto (2014) juga menyebutkan bahwa kenaikan $\mathrm{pH}$ disebabkan oleh beberapa mekanisme yang terjadi selama proses elektrokoagulasi.

Pada hasil tersebut menunjukkan semakin besar arus yang diberikan dan semakin lama waktu kontak sampel maka akan mengakibatkan nilai pH meningkat. Peningkatan nilai pH ini disebabkan besarnya arus dan lamanya waktu kontak akan menghasilkan $\mathrm{OH}^{-}$yang semakin banyak pula. Menurut Yonna (2017) $\mathrm{pH}$ larutan meningkat selama proses elektrokoagulasi karena pembentukan $\mathrm{OH}^{-}$dan gas $\mathrm{H}_{2}$.

Pada waktu kontak 80 menit kenaikan nilai $\mathrm{pH}$ terbesar pada kuat arus 2,2 A yaitu 8,4. Sedangkan pada waktu kontak 50 menit dan 110 menit kenaikan nilai pH terbesar pada kuat arus 1,6 dan 2 A yaitu 8 dan 8,9. Pada waktu kontak 50 menit dengan kuat arus 2 A dan waktu kontak 110 menit dengan kuat arus 2,2 A mengalami penurunan nilai $\mathrm{pH}$. Penurunan $\mathrm{pH}$ ini dikarenakan produksi ion $\mathrm{H}^{+}$ pada saat proses elektrokoagulasi. 


\subsection{Pengaruh Waktu dan Kuat Arus Terhadap Total Kesadahan}

Adapun pengaruh waktu dan kuat arus terhadap total kesadahan pada air payau bisa kita lihat pada gambar 3.3 dibawah ini

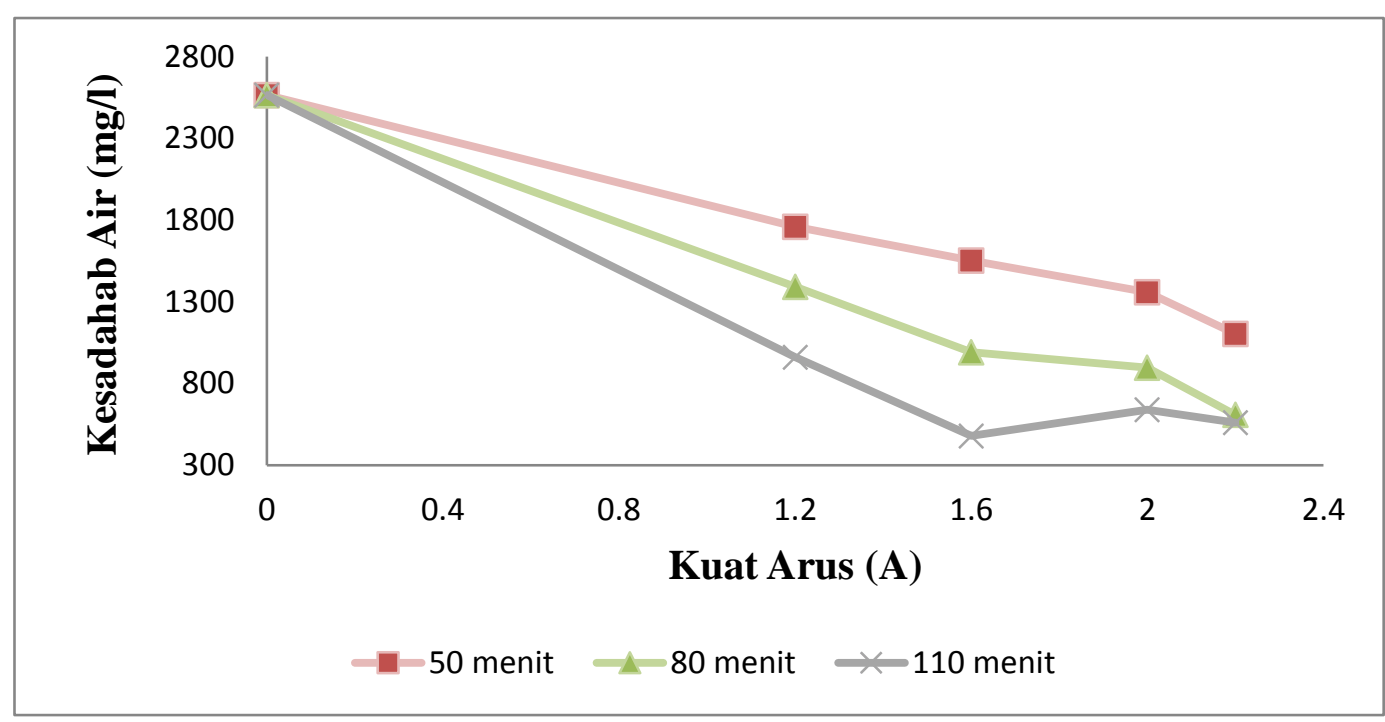

Gambar 3.3 Pengaruh Waktu Kuat Arus Terhadap Total Kesadahan Dalam Sampel Air Payau

Berdasarkan data pada Gambar 3.3, pengaruh waktu dan kuat arus terhadap total kesadahan, dapat kita lihat hasil yang di dapatkan terhadap total kesadahan terjadi penurunan. Semakin besar kuat arus yang di alirkan semakin besar ion aluminium $\left(\mathrm{Al}^{3+}\right)$ yang dihasilkan oleh anoda dan ion hidroksida yang dihasilkan oleh katoda yang berfungsi sebagai koagulan. Koagulan tersebut akan berikatan dengan partikel koloid yang ada di dalam air payau sehingga mulai terbentuk flok. Gas hidrogen yang terbentuk pada katoda membantu flok mengapung atau terangkat sehingga menyebabkan tereduksinya material terlarut berupa ion-ion logam dalam air payau sehigga menyebabkan total kesadahan pada air payau semakin menurun.

Dari gambar 3.3 juga dapat dilihat semakin besar waktu kontaknya maka semakin menurun total kesadahan. Semakin lama waktu proses maka penurunan parameter pencemaran akan semakin baik. Ini juga sesuai hukum faraday yang menyatakn semakin lama waktu proses maka akan semakin banyak koagulan yang terbentuk. 
Pada waktu kontak 50 menit dan 80 menit terjadi penurunan konsentrasi total kesadahan terbesar pada kuat arus 2,2 A yaitu $1104 \mathrm{mg} / \mathrm{l}$, dan $608 \mathrm{mg} / \mathrm{l}$. Sedangkan pada waktu kontak 110 menit penurunan kosentrasi total kesadahan terbesar pada kuat arus 1,6 A yaitu $480 \mathrm{mg} / \mathrm{l}$.

Pada waktu kontak 110 menit dan kuat arus 2 A terjadi kenaikan kembali kosentrasi total kesadahan setelah sebelumnya kuat arus 1,6 A. Hal ini terjadi karena adanya endapan yang menempel pada elektroda aluminium yang digunakan, jadi pada saat proses elektrokoagulasi endapan yang menempel pada elektroda meluruh ke dalam larutan sehingga menambah kosentrasi total kesadahan.

Hasil analisis total kesadahan sampel awal air payau sebelum elektrokoagulasi yaitu $2.656 \mathrm{mg} / \mathrm{l}$. Sampel awal tersebut tidak memenuhi persyaratan baku mutu standar yaitu $500 \mathrm{mg} / \mathrm{l}$. Total kesadahan terendah terjadi pada kuat arus 1,6 A pada waktu kontak 110 menit yaitu 480 mg/l. Pada kuat arus 1,6 A dan waktu kontak 110 menit memenuhi persyaratan baku mutu air bersih.

\subsection{Pengaruh Waktu dan Kuat Arus Terhadap Kosentrasi Mn}

Dari hasil analisis sampel terbaik diambil 110 menit dan kuat arus 1,6 A dapat kita lihat kosentrasi Mn pada awal sampel memenuhi persyaratan baku mutu air bersih yaitu 0,0787 mg/l. Pada kuat arus 1,6 A dan waktu kontak 110 menit terjadi penurunan yaitu $0,0124 \mathrm{mg} / \mathrm{l}$. Hasil tersebut menunjukkan adanya pengaruh kuat arus terhadap percent removal logam Mn. Menurut Yonna (2017) bahwa penyisihan kandungan logam terlarut akan semakin tinggi seiring terbentuknya $\mathrm{Al}(\mathrm{OH})_{3}$. Penyisihan $\mathrm{Mn}$ terjadi ketika semakin banyaknya ion $\mathrm{Al}^{3+}$ yang dihasilkan pada anoda dan membentuk flok $\mathrm{Al}(\mathrm{OH})_{3}$ yang berperan sebagai koagulan. Kemudian flok $\mathrm{Al}(\mathrm{OH})_{3}$ tersebut dapat mengikat senyawa organik dan logam logam yang terkandung dalam air (Saputra dan Farida, 2016).

Pada kuat arus rendah, arus yang dibutuhkan dalam pembentukan $\mathrm{Al}(\mathrm{OH})_{3}$ kurang, sehingga proses elektrokoagulasi kurang efektif. Berikut ini adalah mekanisme penyisihan Mn yang terjadi selama proses elektrokoagulasi.

Anoda $\quad: \mathrm{Al}_{(\mathrm{s})} \rightarrow \mathrm{Al}^{3+}+3 \mathrm{e}$

Katoda $\quad: 2 \mathrm{H}_{2} \mathrm{O}_{(\mathrm{aq})}+2 \mathrm{e} \rightarrow 2 \mathrm{OH}^{-}+\mathrm{H}_{2}$ 
Overall $\quad: \mathrm{Al}^{3+}+3 \mathrm{H}_{2} \mathrm{O}_{(\mathrm{aq})} \rightarrow \mathrm{Al}(\mathrm{OH})_{3(\mathrm{~s})}+3 \mathrm{H}^{+}$

Selama proses, semakin banyak kation alumunium yang terbentuk kemudian membentuk $\mathrm{Al}(\mathrm{OH})_{3}$ yang akan mengikat polutan-polutan atau yang dikenal sweep coagulation yang diikuti mekanisme pengendapan. Kemudian agregat hasil koagulasi tersebut akan berinteraksi dengan gelembung-gelembung dan terflotasi ke permukaan atau mengendap di dasar reaktor. Ion Mn memberi warna kuning dalam bentuk hidroksidanya. Peningkatan volume ini disebabkan pecahnya molekul-molekul minyak akibat suhu yang tinggi sehingga molekul molekul menempati volume yang lebih besar dibandingkan saat suhu rendah (Cuah et al. 2008). Menurut (Noureddini et al. 1992) beberapa minyak yang telah diteliti menunjukkan kecenderungan penurunan densitas secara linier terhadap perbedaan jenis pelarut yang digunakan. Pada penelitian ini nilai densitas yang diperoleh antara 0,85 - 0,87 gr/ml sesuai dengan standar mutu yang ada. Nilai densitas yang paling tinggi adalah $0,964 \mathrm{gr} / \mathrm{ml}$ dan yang paling sedikit adalah sebanyak 0,606 $\mathrm{gr} / \mathrm{ml}$.

\section{Simpulan dan Saran}

\subsection{Simpulan}

Penelitian elektrokoagulasi air payau menjadi air bersih yang telah dilaksanakan, dapat diambil kesimpulan antara lain:

1. Proses elektrokoagulasi mampu menurunkan kadar TDS, kesadahan air, kandungan logam Mn didalam air payau dan juga mampu menetralkan $\mathrm{pH}$.

2. Hasil yang terbaik didapatkan pada $\mathrm{pH}$ pada waktu 50 menit dengan kuat arus 1,2 A yaitu 7,2.

3. Hasil yang terbaik didapatkan pada penurunan total kesadahan pada waktu 110 menit dan kuat arus 1,6 A yaitu 480 mg/l.

4. Hasil yang terbaik didapatkan pada penurunan TDS pada waktu 110 menit dan kuat arus 2,2 A yaitu $940 \mathrm{mg} / \mathrm{l}$.

5. Terjadi penurunan terhadap kosentrasi Mn yaitu $0.0124 \mathrm{mg} / \mathrm{l}$.

6. Terjadi perubahan warna pada air payau setelah proses elektrokoagulasi. 


\subsection{Saran}

Adapun saran yang diperoleh pada penelitian ini adalah:

Diperlukan penelitian lebih lanjut untuk mengetahui pengaruh ketebalan elektroda dan jarak elektroda yang digunakan dan menggunalan air baru saat melakukan penelitian,

\section{Daftar Pustaka}

Alperdo, Jhon. 2019. Pengaruh Kuat Arus dan Laju Alir pada Pengolahan Air Payau menjadi Air Bersih dengan Metode Elektrokoagulasi menggunakan Reaktor Listrik Kontinyu. Fakultas Teknik. Universitas Riau

Alwasyah, Febri. 2019. Pengaruh Laju Alir dan Kuat Arus pada Pengolahan Limbah Cair Industri Pelapisan Logam dengan Proses Elektrokoagulasi secara Kontinu. Universitas Riau

Charlena. 2014. Pencemaran Logam Berat Timbal (Pb) dan Cadnium (Cd) pada Sayur-sayuran. Tesis program Magister Institut Pertanian Bogor. Bogor.

Destrina, Zefrina. 2015. Prototype Alat Pengolahan Air Laut Menjadi Air Minum (Pengaruh Variasi Koagulan Dan Packing Filter Terhadap Kualitas Air Dengan Analisa TDS, DO, Salinitas, Dan Kandungan Logam Mg2+ Dan $\mathrm{Ca}+$ ). Palembang: Politeknik Negeri Sriwijaya.

Djajadiningrat, S. 2014. Kawasan Industri Berwawasan Lingkungan (Eco Industrial Park). Rekayasa Sains, Bandung.

Effendi, H. 2013. Telaah kualitas air. Kanisius, Yogyakarta.

Fitria, D. 2017. Penurunan Warna dan Zat Organik Air Gambut dengan Cara Two Staged Coagulation. Digital Library ITB, Bandung.

Hanum, F. 2015. Aplikasi Elektrokoagulasi Dalam Pengolahan Limbah Cair Pabrik Kelapa Sawit. Jurnal Teknik Kimia USU, Vol 4, No 4.

Holt, P. K., Barton, G.W., Wark, M., Mitchell, C.A. 2010. A quantitative comparison between chemical dosing and electrocoagulation. Colloids Surf, A 211: 233-248.

Kashefi, M. 2014. Efficiency Evaluation Of Electrocoagulation Process For Removal of Chromium From Municipal and Industrial Water. Indian J.Sci. Res. (7) 1258-1268. 
Kurniasih, R. F., Gunawan , R., Panggabean A.S. 2016. Aplikasi Metode Elektrokoagulasi Terhadap Penurunan Logam Fe dan Mn, Kekeruhan Serta Warna Pada Pengolahan Air Gambut Secara Batch. Jurnal Atomik, 1(1)

Mollah, M. Y. A, Robert, S., \& Jose, R.P. 2009. Fundamental Present and Future perspectives of Elektrocoagulation. Journal of Hazardous Material, B114 pp: 199-21.

Nasution M A. 2011 Electrocoagulation of Palm Oil Mill Effluent as Wastewater Treatment and Hidrogen Production Using Electrode Aluminium. J. Environ, Qual.vol 49 1332-9

Ngatin, A. 2010. Pengaruh konsentrasi asam sulfat terhadap effisiensi arus dan pewarnaan pada proses anodisasi aluminium.Politeknik Bandung.

Nurhasni. 2012. Penyerapan Ion Aluminium dan Besi dalam Larutan Sodium Silikat Menggunakan Karbon aktif. Program Studi Kimia FST UIN Syarif Hidayatullah, Jakarta.

Pangesti, Ana. 2013. Ekosistem Air Payau dan Permasalahannya. Diakses 24 Februari 2016.

Prabowo, A. dan H. B. Gagah. 2012. Pengolahan limbah cair yang mengandung minyak dengan proses elektrokoagulasi dengan elektroda besi. Jurnal teknologi kimia dan industri, Vol 1, No 1: 352-355.

Saputra, E. dan H. Farida. 2016. Pengaruh jarak antara elektroda pada reactor elektrokoagulasi terhadap pengolahan effluent limbah cair pabrik kelapa sawit. JurnalTeknik Kimia USU, Vol 5: 4.

Siringgo-ringgo, E. 2012. Penggunaan Metode Elektrokoagulasi Pada Pengolahan Limbah Industri Penyamakan Kulit Menggunakan Alumunium Sebagai Sacrificial Elektrode. Jurnal Sains dan Teknologi Kimia.

Surdia, T. 2013. Teknik Pengocoran Logam. Cetakan Ke-6 PT. Pradnya Paramitha. Jakarta

Suripin. 2012. Pelestarian SumberDaya Tanah dan Air. Andi. Yogyakarta

Tarigan, M.S., \& Edward. (2013). Kandungan total zat padat tersuspensi di perairan raha, sulawesi tenggara. Jurnal Makara, 7 (3), 2013

Wiyanto, E., Budi, H., Amelia, A., Rudy, P., Julita., \& Mario,S.K. 2014. Penerapan elektrokoagulasi dalam proses penjernihan limbah cair. Jurnal Ilmiah Teknik Elektro Trisakti, Vol 12, No 1: 19 - 36. 
Wulandari, A. 2009. Penanganan Hasil Perairan di Pelabuhan Ratu, Sukabumi, Jawa Barat. [Skripsi]. Bogor: Teknologi Hasil Perairan, Fakultas Perikanan dan Ilmu Kelautan. Institut Pertanian Bogor. Hal.

Yonna, Y., Shinta, E., \& Ivnaini, A. 2017. Metode Elektrokoagulasi untuk Mengolah Limbah Cair Batik di Unit Kegiatan Masyarakat Rumah Batik Andalan PT. Riau Andalan Pulp and Paper (RAPP). 